\title{
Analysts see 'tale of two CEOs' unfolding at Pfizer and Merck
}

"It was the best of times, it was the worst of times..." Charles Dickens may not have lived during the age of blockbuster drugs such as Lipitor and Vioxx, but his writing captures the state of the pharmaceutical industry. Although product pipelines are drying up, the emergence of new markets, coupled with the advent of personalized medicine and other advances, offer exciting opportunities for drugmakers. And, given the unpredictable drug-development environment, analysts are keeping a watchful eye as a 'tale of two CEOs' unfolds at two top pharmaceutical firms.

This year kicks off with new chief executives at two of the largest drugmakers, New Jerseybased Merck and Pfizer, headquartered in New York. One leadership change seems to show a company sticking to a carefully plotted course. The other, a more unexpected switch at the helm, reveals a pharmaceutical giant with a fluctuating business approach.

At the start of January, Kenneth Frazier stepped into the position of chief executive of Merck. According to Connecticutbased pharmaceutical analysis firm IMS Health, Merck became the second-largest pharmaceutical company, on the basis of global sales, with its acquisition of its longtime partner company, New Jersey-based ScheringPlough, in November 2009. Analysts describe the executive move as a well-choreographed progression of leadership.

Frazier, best known for leading the company's legal defense and public relations efforts after claims that the painkiller Vioxx caused heart attacks and strokes, is taking over from Richard Clark, who is stepping down as a result of the company's mandatory retirement age.

Clark was known as an aggressive leader with his own focus on emerging markets and investment in relatively high-risk research and development. Merck's stock is now approximately 20\% higher than when Clark took over in 2005. It's still unclear whether Frazier will take a similar tack, but, notably, Clark will stay on as chairman and will continue to advise Frazier.

"Frazier is a smart team player who takes a very strategic approach to things. He's been in line for the position for a while, so don't expect much change," says William Ashton, an expert in pharmaceutical and healthcare business at the University of the Sciences in Philadelphia.

Along with a pipeline of promising cancer drugs, the company has four cardiovascular drugs in late-stage testing. However, it remains to be seen whether any have the potential to replace Merck's best-selling product, the $\$ 4.7$ billion asthma and allergy treatment Singulair,
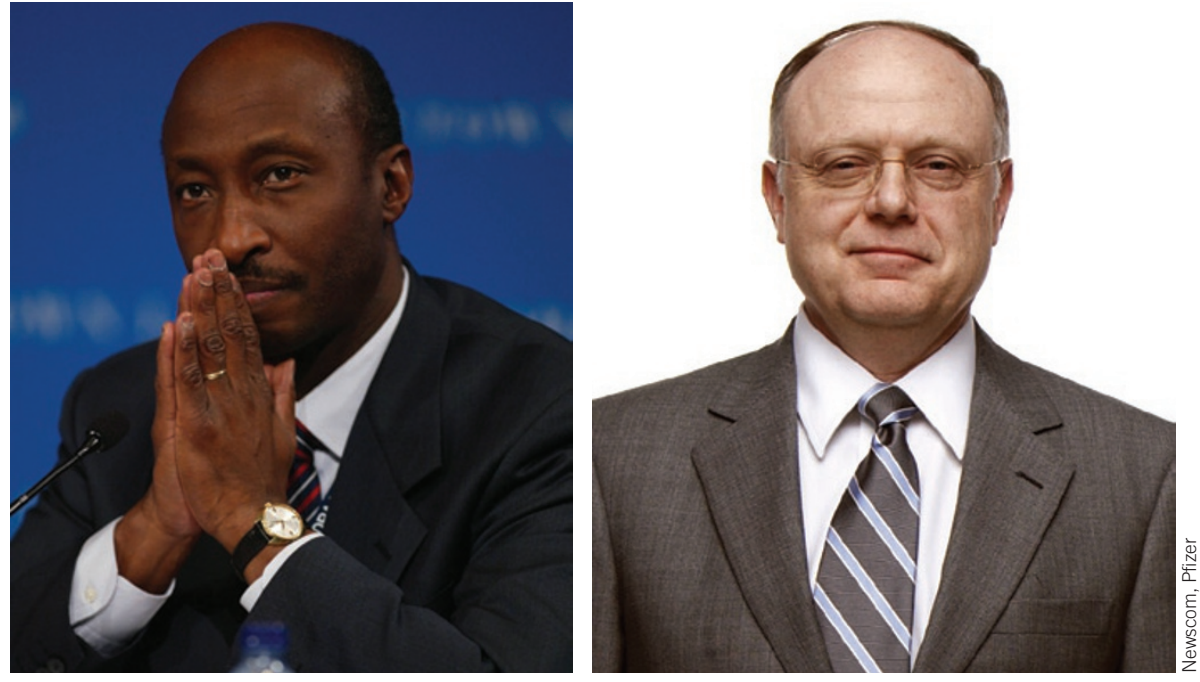

Steering the ships: Kenneth Frazier (left) and Jeffrey Kindler.

which is due to go off patent in August 2012.

The world's largest pharmaceutical company, Pfizer, recently underwent a more radical leadership change. In early December, Pfizer's CEO and chairman Jeffrey Kindler abruptly resigned from his position after four and a half years in the post and after just nine months as board chairman of the Pharmaceutical Research and Manufacturers of America.

The consensus among analysts is that he was most likely forced out because of the company's nearly 30\% drop in stock price during his term. Kindler, seen as an outsider with a background at companies such as McDonald's, is said to have faced skepticism from investors since the beginning of his tenure. In addition, he drew ire from some stockholders as an advocate for Obama's healthcare reform package.

With the potential of new blockbuster drugs waning, Kindler enacted a strategy of mergers and acquisitions to acquire the pipelines and resources of other companies, the largest of which was the October $2009 \$ 68$ billion acquisition of Wyeth. This acquisition tied up some of the company's resources for much of 2010 and has yet to bear fruit, according to Anthea Zhang, an expert in investment analysis at Rice University in Houston, Texas.

\section{Reading into the future}

Patent-protection lapses this year on Lipitor, an $\$ 11.4$ billion cholesterol drug that is estimated to account for $23 \%$ of the company's global sales, so Pfizer's new CEO, Ian Read, must find a way to counteract the loss.

Some analysts expect Read's substantially different background prompt a shift in company strategy. As opposed to Kindler, Read is seen as a cooperative insider who has worked within the company for many years; furthermore, he has undergraduate training in chemical engineering.

"Another of Read's strengths-besides that fact that he's been in the company for 32 years and is very well respected-is that he understands global and emerging pharmaceutical markets better than Kindler," Zhang says.

Read is also expected to look to diversification as a way to stabilize the company, drawing on acquisitions such as Wyeth. This approach is being taken by GlaxoSmithKline (where Andrew Witty took over as CEO in 2008), which has invested in diverse products such as flea sprays.

Last year also witnessed the replacement of longtime Novartis head Daniel Vasella with Joe Jimenez, a newcomer to the pharmaceutical industry whose experience is in packaged goods at companies such as ConAgra Foods. Novartis faces the patent loss of the $\$ 6$ billion hypertension treatment Diovan in 2012, but it has recently raised profits through the sale of flu vaccines.

More changes are coming down the pike. For example, Johnson \& Johnson CEO William Weldon is expected to retire within the year and New Jersey-based Savient Pharmaceuticals is on the hunt for its next chief executive.

"The pharmaceutical industry is changing faster than ever in the form of new markets, new technology and new regulations-and with that comes moves in leadership," says Pearl Freier, president of Cambridge BioPartners, an executive search firm for the pharmaceutical industry. "Whether anyone has the right answers, though, only time will tell."

Stu Hutson 